\title{
15 Graduate Students Receive MRS Awards
}

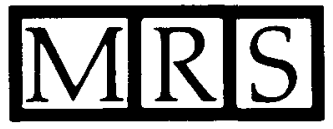

Fifteen graduate students representing various materials science disciplines were selected as recipients of the MRS Graduate Student Awards to be conferred in conjunction with the 1985 MRS Fall Meeting.

Award winners and their papers are:

John Charles Barbour, Dept. of Materials Science and Engineering, Cornell University, "High Spatial Analysis of Lateral Silicide Formation" (Symposium E) and "Diffusion in Amorphous $\mathrm{Ni}-\mathrm{Zr}$ Alloys" (Symposium I) Peter H. Bischoff, Dept. of Civil Engineering, Imperial College of Science and Technology (UK), "Compressive Strain Rate Effects of Concrete" (Symposium S)

Suzana Clement, Dept. of Physics, Universidad Complutense (Spain), "Radiation Induced Impurity Precipitation in $\mathrm{MgO}^{\prime \prime}$ (Symposium L)

Aliki Collins, Dept. of Materials Science, Massachusetts Institute of Technology, "Magnetic After Effects and Magnetostriction of Fe-base Glasses" (Symposium ))

B.C. DeCooman, Dept. of Materials Science and Engineering, Cornell University, "The
Defect Structure of Ion-Implanted $\mathrm{Al}_{x} \mathrm{Ga}_{1-x}$ As/GaAs Superlattices" (Symposium H) and "TEM Study of the Core-Structure of Dislocations in GaAs" (Symposium Q)

Vladimir Dobrosavljevic, Dept. of Physics, Brown University, "Conformational Induced Disorder and Conjugated Polymer Spectroscopy" (Symposium F)

R. W. Fathauer, Electrical Engineering, Cornell University, "Heteroepitaxy of $\mathrm{Si}$ and Ge on $\mathrm{CaF}_{2} / \mathrm{Si}(111)$ " (Symposium E)

John J. Joyce, Dept. of Chemical Engineering and Materials Science, University of Minnesota, "Characterization of an Extended Reactive Noble-Metal/III-V Semiconductor Interface: CuGaAs(110)" (Symposium E)

Amitabha Kumar, Solid State Science, Pennsylvania State University, "Diffusion and Pore Structure of Portland Cement Pastes Blended with Low Calcium Fly Ash" (Symposium T)

Kenneth T.-Y. Kung, Dept. of Electrical Engineering and Computer Science, Massachusetts Institute of Technology, "ImplantDose Dependence of Seed Selection through

\section{for your GUSTOM-ENGINEERED GERAMIL-METAL DEVIGES:}

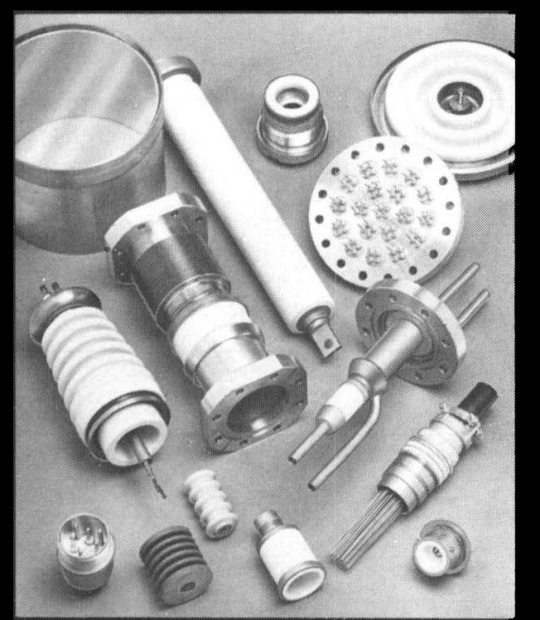

COME TO EXPERIENCE: When a standard product won't solve your problem, turn to Ceramaseal for a special unit. We've engineered and manufactured custom devices since 1951 for a wide range of markets.

VERSATILITY: Using both the refractory- and active-metal processes, we can offer many metal-ceramic combinations

PERFORMANCE: Designs withstand temperatures from $-268^{\circ} \mathrm{C}$ to $+1000^{\circ} \mathrm{C}$, operating pressures from $<1 \times 10^{-1}$ torr to $>30,000 \mathrm{psig}$, voltages to 180 $\mathrm{KV}$

STANDARD UNITS, TOO: We have hundreds of designs available from stock for immediate shipment.

\section{staeramaseal}

A Division of Clevepak Corporation

P.O. BOX 25, NEW LEBANON CENTER, NEW YORK 12126 (518) 794-7800 • TELEX $14-5442$
Ion Channeling to Enhance the (110) Texture of Low Pressure Chemical-Vapor Deposited Polycrystalline Si Films on $\mathrm{SiO}_{2}$ (Symposium $C$.

John D. Lennhoff, Dept. of Chemical Engineering, Worchester Polytechnic Institute, "Direct Synthesis and Characterization of High Surface Area Solid State Inorganics for Catalysts and Ceramics" (Symposium $M$ )

Carolyn A. MacDonald, Applied Physics, Harvard University, "The Kinetics of Rapid Crystallization in Pure Metals" (Symposium A)

Karren L. More, Dept. of Materials Engineering, North Carolina State University, "Laser and Ion Beam Surface Modification of $\alpha$-SiC" (Symposium $A)$

Michael A. Parker, Materials Science Dept. Stanford University, "Direct Observation of the Amorphous-to-Crystalline Phase Transformation in Silicon by In-Situ HighResolution Transmission Electron Microscopy" (Symposium Q)

Chris G. Van de Walle, Electrical Engineering, Stanford University, "Theoretical Study of Semiconductor Interfaces" (Symposium R)

"It is an honor for the Society to recognize these outstanding young scientists," remarked Woody White, chairperson of the Awards Committee. "An MRS Graduate Student Award is one of the most prestigious awards that a graduate student can achieve," White said. "The Awards Committee is pleased to be able to recognize almost twice as many students as in 1984 because of the enormous number of highquality applications submitted. These young scientists, representing fields of study such as physics, computer science, solid state science, and electrical, chemical and civil engineering, are the future of materials research and this Society. And by the caliber of these papers, it is evident that it will be a bright future."

The Graduate Student Award consists of a plaque and cash honorarium. The awards will be conferred Monday evening, December 2, at 6:30 p.m. in the Grand Ballroom of the Boston Marriott/Copley Place.

The MRS Graduate Student Awards Program was established in 1980 to recognize the achievements and promise of those studying one or more disciplines involved in materials research. 
Metal Ion Implant Services

Ion implantation service for metal surface modification solves wear, erosion, and corrosion problems. We offer fast, accurate, high quality processing to meet your most demanding requirements.

- Five ion implanters

- $\mathrm{Cr}^{+}, \mathrm{N}^{+}$, and other ions

- Special tooling

- lon beam mixing

- Tribological diagnostics

- Sputtering and plasma deposition as well

\section{Call}

\section{Metals Ion Implant} (617) 275-6000

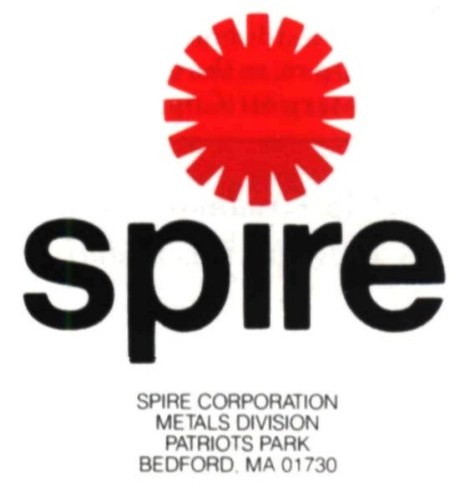

\section{NOTICE TO MRS MEMBERS}

\section{YOUR SUBSCRIPTION TO \\ MATERIALS LETTERS IS EXPIRING}

As a member of the Materials Research Society, you have been receiving a complimentary subscription to Materials Letters which will expire at the end of Volume III (Volume III will be completed in the fall). MRS has arranged a way for you to continue your subscription by negotiating a special low rate with the publisher. To receive Volume IV of Materials Letters you need only pay $\$ 17.50$. Personal subscriptions to Materials Letters are available only to MRS members, and this special rate enables you to continue to receive this publication at minimal cost.

This new optional subscription program enables the Society to provide continuity to the members who have expressed a desire to continue receiving Materials Letters, while expanding its dues-supported benefits package to include a subscription to the new Journal of Materials Research beginning in 1986.

\section{REMEMBER}

As an MRS member in 1986, you will automatically receive Journal of Materials Research as part of your membership dues, but can also maintain an exclusive personal subscription* to Materials Letters at a small charge. Return this order form immediately to the Materials Research Society with your payment of $\$ 17.50$ if you wish to receive Volume IV of Materials Letters.

*Institutional subscriptions for your library must be obtained through the publisher, Elsevier Science Publishers B. V., Journal Department, P.O. Box 211, 1000 AE Amsterdam, The Netherlands.

\section{SUBSCRIPTION TO VOLUME IV OF MATERIALS LETTERS}

Name

Organization

City State Zip/Postal Code

Country

Please enter my personal subscription to Materials Letters for Volume IV. I am a member of MRS and enclose my subscription payment of $\$ 17.50$

Return to: Materials Letters Subscription, Materials Research Society, McKnight Road, Suite 327, Pittsburgh, PA 15237; telephone (412) 367-3003.

Make checks payable to Materials Research Society. 